University of Wollongong

Research Online

Faculty of Arts - Papers (Archive)

Faculty of Arts, Social Sciences \& Humanities

6-12-2011

\title{
'The closet of the third person'; Susan Sontag, sexual dissidence, and celebrity
}

Guy R. Davidson

University of Wollongong, guy@uow.edu.au

Follow this and additional works at: https://ro.uow.edu.au/artspapers

Part of the Arts and Humanities Commons, and the Social and Behavioral Sciences Commons

\section{Recommended Citation}

Davidson, Guy R., 'The closet of the third person'; Susan Sontag, sexual dissidence, and celebrity 2011, 387-397.

https://ro.uow.edu.au/artspapers/1163

Research Online is the open access institutional repository for the University of Wollongong. For further information contact the UOW Library: research-pubs@uow.edu.au 


\section{"The Closet of the Third Person": Susan Sontag, Sexual Dissidence, and}

\section{Celebrity}

1

The reluctance of the novelist, essayist, and celebrity intellectual Susan Sontag to come out as lesbian or bisexual was, in the decade or so before her death in 2004, one of the most well-known facts about this very well-known individual. Celebrity has been defined as the point at which the public figure engages interest at the level of private life. ${ }^{i}$ Celebrities themselves, however, especially queer ones, are often anxious to bar access to information about their erotic lives, and this was very much the case with Sontag. In an interview from the early 1990s, when reporters were starting to ask questions about her sexuality, she stated, "I don't talk about my erotic life any more than I talk about my spiritual life. It is ... too complex and it always ends up sounding so banal" (qtd. in Seligman 102-3). Later she declared rather stuffily, “indiscretion about one's unconventional sexual feelings is now a routine, if not mandatory, contribution to public entertainment" (Where the Stress Falls 104; qtd. in Seligman 103). Only in 2000, when an unauthorized biography detailing her love affairs with women was about to appear, did Sontag pre-emptively half-acknowledge what had by then become an open secret. In an interview in the New Yorker, she said: "That I have had girlfriends as well as boyfriends is what? Is something I never thought I was supposed to say since it seems to me the most natural thing in the world" (qtd. in Seligman 103). The throwaway disingenuousness of the remark is matched by its intellectual shoddiness: the Sontag who in previous years had 
written bracingly about the cultural meanings of the erotic would hardly have countenanced this airy relegation of "unconventional sexual feelings" to the realm of the "natural," that is, the not-worth-mentioning. Moreover, Sontag's brief marriage to the University of Chicago sociologist Philip Rieff, with whom she had a son, David, secured for her for many years a nominal public identity as a heterosexual. And it's not true that she never spoke about her erotic life. Most strikingly, in an interview with Rolling Stone from 1978, Sontag speaks at some length on this topic, though in carefully degendered terms (Conversations 124-28). My aim in this essay, however, is neither to upbraid Sontag for her lack of openness, nor to express disappointment that such an influential individual should have proved unwilling to come out earlier and more definitively. Instead, I wish to attend to the elision and articulation of what Jonathan Dollimore calls sexual dissidence in Sontag's work - to suggest some of the ways in which despite or indeed because of her reticence, queer sexuality centrally informed her career. The term sexual dissidence has taken on a life of its own since Dollimore used it as the title for his wide-ranging 1991 study of the place of homosexuality in Christian and post-Christian culture, carrying as it does the politically useful connotation of active disagreement with heteronormativity. But the examples of active disagreement that Dollimore discusses - like the cultural and textual materials discussed by queer theory generally - tend to operate through subversion rather than open challenge, a mode of dissent necessitated by the severe punishments that have long rained down upon queer people. In the spirit of queer-theoretical enquiry into the possibilities of the 
subversive text, I want to suggest that the interplay between the disclosure and obfuscation of sexual dissidence in Sontag's work can be connected to various tensions in her career: the tension between modernism and postmodernism, and, related to this, the tension between her espousal of the modernist shibboleth of impersonality and her celebrity status. In particular, I draw upon Eve Kosofsky Sedgwick's claim that "any aspect of Western culture must be, not merely incomplete, but damaged in its central substance to the degree that it does not incorporate a critical analysis of modern homo/heterosexual definition" (Epistemology 1).

The tendency to read Sontag's essays and fiction as a kind of veiled life writing has become an established approach in studies of her work; indeed, at least insofar as the essays in particular function as kind of intellectual autobiography, this critical tendency was accorded Sontag's own imprimatur. In a prefatory note to Against Interpretation (1966), the collection of the essays from the early 1960s with which she made her name, Sontag stated that "in the end what I have been writing is not criticism at all, strictly speaking, but case studies for an aesthetic, a theory of my own sensibility" (viii). Later, in an essay on Walter Benjamin from 1978, Sontag wrote, “One cannot use the life to interpret the work. But one can use the work to interpret the life" (Under the Sign of Saturn 111); and critics have deployed this aperçu as a license to probe Sontag's work for its autobiographical resonances. Sontag herself noted in a 1984 interview that her essays on Benjamin, Elias Canetti, and Roland Barthes were "portraits that are in some sense self-portraits" (Conversations 208). On the other hand, in 
“Singleness," an essay from 1995, she repudiated psychologizing interpretations, stating, "my books are not a means of discovering who I am either; I've never fancied the ideology of writing as therapy or self-expression" (Where the Stress Falls 260). But the first person always hovered tantalizingly behind the usually third-person mode of Sontag's expression - as her own statements indicate, acknowledging and then withdrawing the first-person presence in a kind of fort/da game with her readers.

In what follows, I draw upon and extend the critical tendency to use Sontag's "work to interpret the life," juxtaposing a reading of the essays - in particular those collected in Against Interpretation and especially "Notes on Camp" - with a reading of Reborn, a recently published selection from Sontag's journals and notebooks, the first volume of a projected three. If in her essays Sontag implicitly and self-reflexively raises the possibility of an autobiographical reading of a prose famous for its impersonality, what difference does it make that we now have available the journals in which the first person, rather than being covertly expressed, dramatically emerges? Covering the period from 1947 to 1963 - from her adolescence in Los Angeles to her early years in New York, where she began to establish herself as a writer - Reborn is unstintingly frank about her erotic relations with women and her identification as a lesbian, providing a near-shocking contrast to the reticence with which she treated her sexual life in her public utterances. On the most obvious level, the journals begin to provide the missing piece of the puzzle that Sontag herself withheld, enabling an understanding of the sexual and sentimental autobiography to put alongside 
the intellectual autobiography that may be gleaned from her essays and interviews. But I want to suggest that the sexual-more specifically, the homosexual - and the intellectual were entwined in Sontag's published work from the beginning. While the journals provide an invaluable resource for thinking through the difference Sontag's sexuality made to her career, I am not primarily interested in the extent to which the journals round out our understanding of her sexual identity; rather, I read the indirect life writing of the essays in juxtaposition with the life writing proper of the journals in order to parse the persistence as well as the changes in the interrelation of celebrity, selfconception, and sexuality in Sontag's life and work.

\section{2}

Against Interpretation is often regarded as championing the new modes of art and aesthetic appreciation collected under the rubric "postmodernism." Alongside essays on established figures such as Albert Camus and Georg Lukács, the book includes celebrations of such avatars of what Sontag called "the new sensibility" as Jean-Luc Godard, Nathalie Sarraute, and - several rungs down the ladder of cultural respectability - science-fiction movies, and Jack Smith's Flaming Creatures (1963), the New York underground film banned for shots of nudity and masturbation. It has rightly been pointed out that Sontag's investment in unsanctioned and popular forms of culture has been overstated, as Sontag was primarily a champion of the rigors of modernism. Nevertheless, the challenges she issued to the entrenched devotion to high culture that characterized midtwentieth-century U.S. intellectual life formed an indelible aspect of her public 
image, despite her tendency, as her career progressed, to emphasize the importance of artistic canons and intellectual seriousness.

Sontag also seems aligned with the postmodern in her status as a muchphotographed celebrity - her participation in what Fredric Jameson describes in his well-known definition of postmodernity as "a whole new culture of the image or the simulacrum" (6). If Sontag declined to make explicit her sexual dissidence, her persona was, due to these ubiquitous images of her striking beauty, highly sexualized - in 1967, in a passage from his memoir Making It to which I'll return, Norman Podhoretz dubbed her the “Dark Lady of America Letters." But Sontag disavowed her own participation in the postmodern mediascape and her own celebrity status. She actually denounced the pervasiveness of photography in her book-length essay On Photography (1977) and the pervasiveness of TV unrelentingly in interviews throughout her career. With regard to her mass media fame, in an interview with Richard Bernstein from 1989 she insisted, "My life is entirely private. My interests are not those of a pop celebrity," but that "still, the legend" of her active pursuit of publicity "goes on." Sontag disavows the actuality that in the late twentieth century the status of celebrity can extend not only to pop culture figures but also to novelists and intellectuals.

Also in tension with her much-photographed and much-interviewed presence, Sontag claimed, as a writer, to be more interested in self-transcendence than in self-expression. Both her fiction and the work of the writers and thinkers she promoted in her essays share concerns with self-emptying and negation. In 
her published work she generally eschewed conventional life writing, and the prose style of her essays, as I've intimated, is characterized by a detached urbanity. If Sontag's initial statements of her aesthetic and her immersion in the society of the spectacle align her with postmodernism and postmodernity, her prose style connects Sontag to the impersonality of high modernism.

On one level, the conflict between Sontag's stance of impersonality and her celebrity profile is quite characteristic of literary modernism. Loren Glass notes the striking contrast between the "theories of self-effacement" promulgated by the primary spokespeople for modernism and "their actual practice and literary-historical destiny of self-aggrandizement and even shameless selfpromotion" - exemplified, for instance, in the transformation of T.S. Eliot, propagandist for poetry as an "escape from personality," into "the object of an international personality cult, eventually appearing on the cover of Time" (5). But while the modernists attempted to maintain a distance between their projects and the hubbub of popular culture (even if they sometimes incorporated elements of that hubbub into their own work in the service of ironic critique), Sontag, articulating "the new sensibility," openly embraced commercialized entertainment.

Of the essays collected in Against Interpretation, it was "Notes on Camp" that had the most impact. The essay - in which Sontag variously defines camp as mode of appreciation, a variety of cultural artefact, and a perception of "the theatricalization of experience" (287) - was first published in the fall 1964 issue of Partisan Review, which had a circulation of less than 10,000 , but it went on to have 
a life in less rarefied media outlets. In December of 1964 Time published a summary of the essay, thereby precipitating the mainstreaming of camp, a phenomenon perhaps most famously exemplified by the self-conscious ironies of the Batman TV series that began in 1966. Batman was an example of what Sontag in her essay called "deliberate Camp ... Camp which knows itself to be camp," and which she declared generally less satisfying than "pure" or "naïve" camp (282). In a famous formulation, Sontag proposes that the essence of pure or naïve camp is a "failed seriousness" that elicits laughter or delight from its knowing audience (287). That audience, Sontag notes, is "by and large" homosexual (290). Indeed, she states that camp is "a private code, a badge of identification even, among small urban cliques" (275): a coded rendition of codification that indicates the role of camp as a mode of solidarity in pre-liberation metropolitan gay culture. The association with gay culture is compounded by the essay's designation of Oscar Wilde as its dedicatee and tutelary spirit: Wilde's epigrams provide the framework for the essay which, as the title promises, comprises a series of "notes" rather than a carefully elaborated argument.

In one of the most controversial moments from this essay, Sontag declares: "I am strongly drawn to Camp, and almost as strongly offended by it. That is why I want to talk about it, and why I can. ... To name a sensibility, to draw its contours and to recount its history, requires a deep sympathy modified by revulsion" (276). The overkill of that modifying "revulsion" has been taken by hostile gay readers of "Notes on Camp" to indicate the "phobic dehomosexualization of camp" that the essay as a whole performs (Miller, 
"Sontag's Urbanity" 213). More reasonably, Mark Greif proposes that Sontag's distancing herself from camp was perhaps "a fair caution to take ... considering the social penalties that might be incurred by an unknown defender of homosexual 'sensibility' who became too explicit"; he notes that in 1964 Sontag was afraid that the wrong disclosures about her personal life could lose her custody of her son. Yet at the time Sontag's promotion of camp taste was also daring, even courageous. Time noted that "Miss Sontag was not one to deny" the homosexual implications of camp (qtd. in Rollyson and Paddock 86).

Setting out the motivation for her essay in personal terms, as Sontag does in "Notes on Camp" with the introduction of the speaking I who is both drawn to and offended by camp, is for her an unusual and, it seems now, telling move. The distancing from gay men is real but so is the identification. If Sontag's impersonality is, on her own account, always tinctured by the personal, this uneasy association with gay men can be, and has been, read as a gesture towards as much, as it is an effacement of, her own "unconventional sexual feelings." Terry Castle, for instance, claims that "viewed in hindsight," "Notes on Camp" forms part of "a coy yet now-unmissable 'coming out'" (29). The perspective of hindsight is crucial, though; for many of Sontag's gay critics, in the days before her lesbianism became common knowledge, did "miss" this aspect of the essay. If Sontag comes out here, she indeed does so "coyly." On one level, a coy coming out seems oxymoronic; but Castle's formulation also gets at the intertwined dynamics of disclosure and repression that define homosexuality in modernity and postmodernity. "Notes on Camp," that is, can be understood as 
operating according to the logics of the open secret and the closet, which queer critics, led by D.A. Miller and Eve Kosofsky Sedgwick, have argued are indispensable conceptual tools for understanding the reticulation of power and knowledge around queer identity from the late nineteenth century on.

In an analysis of Wilde's novel The Picture of Dorian Gray, Sedgwick distinguishes, yet also points to the overlap, between the "open secret" of homosexuality and the "empty secret" of "male high modernism" that "delineates... a split between content or thematics on the one hand and structure on the other that is stressed in favor of structure and at the expense of thematics" (Epistemology 165). An examination of male high modernism through the lens of antihomophobic critique, according to Sedgwick, suggests that the figuration that has had to be abjected is the figuration of "the desired male body" (167). The modernism of such writers as Henry James, Ernest Hemingway, and Wallace Stevens is therefore a homophobic practice that bears traces of a repressed homeroticism. The argument has not been uncontroversial. But it is, I think, suggestive for an account of Sontag's entangled relations to modernism and to homosexuality.

Sontag, as a good modernist, also champions "structure over thematics." Yet she does so in Against Interpretation as a means of promoting what has come to be known as postmodernism, in which, as she puts it, "many established distinctions between form and content, the frivolous and the serious, and 'high' and 'low' culture" are dismantled" (297). Sontag's challenge to the moribund 
devotion to high culture takes the form of an appeal to the sensuous rather than the cerebral properties of art. Because, she writes,

the new sensibility ... is more open to the pleasures of form and style, it is also less snobbish, less moralistic - in that it does not demand that pleasure in art necessarily be associated with edification. If art is understood as a form of discipline of the feelings and a programming of sensations, then the feeling (or the sensation) given off by a Rauschenberg painting might be like that of a song by the Supremes. (303)

In pitching the case for her aestheticism by invoking sensuous enjoyment, Sontag recalls Wilde, as well as another crypto-gay theorist, Wilde's teacher Walter Pater. In the preface to Studies in the History of the Renaissance (1873) Pater declares that "the aesthetic critic regards all objects with which he has to do ... as powers or forces, producing pleasurable sensations, each of a more or less peculiar and unique kind" (xxx). But while Wilde and Pater made cautious and indirect connections between the sensuous qualities of art and the erotic, in the statement that closes Against Intepretation's title essay - “In place of a hermeneutics we need an erotics of art"(14) - Sontag fully collapses the sensuous with the sexual. Through her implicit and explicit identifications with dead gay male aesthetes and contemporary gay male culture, and through her twisting of the formalist poetics of modernism into an endorsement of the postmodern, Sontag embeds queerness in seemingly sober and impersonal prose.

In an interview from 1984 Sontag speaks of her desire "to come out of the closet of the third person and speak in a more direct way," a desire which, she 
says, was driving her away from the essay form and back to fiction (Conversations 208). The figure strikingly captures not only the way in which the essays functioned as a kind of closet but also the way in which the closet enables the articulation of identity, even as it apparently secretes it. In the closeted expression of the essays, the first person indirectly emerges in the very act of its repression. And that first person is not simply a composite of aesthetic and intellectual perceptions, but to a pervasive and perhaps surprising extent sexualized. Mark Grief notes that "an odd, partly disowned, seemingly extraneous but electrifying language of sex serpentines through ... many of [Sontag's] essays." Sontag cast such a powerful sexual aura not only because of her much-photographed good looks, or the interest in sexually radical texts and topics that characterized her 1960s work, but also because of the language of her essays, even if that language was "partly disowned."

On one level, Sontag's journals also act as a mode of closeted expression a place in which the "truth" of sexual identity is secretly articulated. But the first person is here unfettered, and the language much franker. In 1948 the fifteenyear-old Sontag notes, "I feel that I have lesbian tendencies (how reluctantly I write this)." Though her reluctance to put her lesbianism down on paper indicates the shame that unsurprisingly accompanied such a realization in the late 1940s, her reflections on her sexuality are from the start shot through with defiance. In the same entry, she writes, "I am very young, and perhaps the disturbing aspect of my sexual ambitions will be outgrown - frankly I don't care" (Reborn 11). Sontag did not wait long to act on her "sexual ambitions": as a 
sixteen-year-old already attending Berkeley, Sontag was introduced to the delights and discomfitures of San Francisco gay and lesbian nightlife by her lover Harriet Sohmers. The certainty of Sontag's orientation seems to have wavered with her marriage at the age of seventeen to Rieff, though the precise motivations on her part are mysterious: the journals give no clue, breaking off at the time of the marriage, and resuming two years later when Sontag was chafing to free herself from it.

In a 1957 entry Sontag describes reading “a curt, unfair, uncharitable assessement" of herself in Sohmers' journal (165). Sontag asks herself, "Do I feel guilty about reading what was not intended for my eyes?," answering: "No. One of the main (social) functions of a journal or diary is precisely to be read furtively by other people (like parents + lovers) about whom one has been cruelly honest only in the journal" (165). Sontag's argument that the private journal always half-consciously solicits a reading public of one's intimates anticipates D.A. Miller's argument about the modern regime of the open secret. Drawing on Foucault's analysis of the disciplinary society, Miller argues that the private subject is produced by a carceral "social totality." The paradoxical phenomenon of the open secret "registers the subject's accommodation to a totalizing system that has obliterated the difference he would make" (The Novel and the Police 207). On this reading, sexual identity - supposedly the most private substratum of the self - is public through and through, produced by and always implicated in the social world from which it is fondly imagined to provide a refuge. Although it is perhaps ultimately more useful to think of interiority and sociality as necessarily 
bound up with one another rather than isomorphic, Miller's argument-and Sontag's reflections - draw our attention to the incestuous relations of public and private utterances.

While it betrays the rhetorical efficacy of both journals and essays to suggest that they are talking about the same things in the same way, the journals enhance our understanding of the extent to which Sontag's "sexual ambitions" were connected to her intellectual ambitions. In one passage from 1959 she writes, "The orgasm focuses. I lust to write. The coming of orgasm is not the salvation but, more, the birth of my ego. I cannot write until I find my ego. The only kind of writer [I] could be is the kind who exposes himself" (218). Then, in another entry from a few days later: "My desire to write is connected with my homosexuality. I need the identity as a weapon, to match the weapon that society has against me.... Being queer makes me feel more vulnerable. It increases my wish to hide, to be invisible - which I've always felt anyway" (221). For Sontag, queer sexuality lies at the heart of contradictory desires to expose oneself and to hide within writing. These contradictory desires were to be played out in a career as a celebrity writer who barred talk of her queerness, and in an impersonal writing which encoded the deeply personal fact of that queerness. But in Against Interpretation, that encoded admission was not simply evidence of the way in which, as Foucault argues about the post-Enlightenment regime of sexuality, "the obligation to conceal [sex] [is] but another aspect of the duty to admit to it" (61). Queerness was also used in Sontag's writing, as she says, as a "weapon" - a subtle and subversive weapon, but a weapon 
nonetheless - a weapon against the orthodoxies of mid-century American intellectual life.

\section{3}

There is a sense, however, in which Sontag's rebellious impulse in Against Interpretation outran her. One motivation of "Notes on Camp" is the attempt to validate an "aristocratic" imperative of taste-making. As Sontag stresses, somewhat in tension with her rejection of the "snobbish" tendencies of "the old sensibility," "the history of Camp taste is part of the history of snob taste" (290). "Camp," Sontag announces, "is the answer to the problem: how to be a dandy in the art of mass culture" (288). Rather than collecting and consuming rare objects like the nineteenth-century dandy, the modern camp aesthete "learns to possess" common objects "in a rare way": "Camp ... makes no distinction between the unique object and the mass-produced object. Camp taste transcends the nausea of the replica" (289). But if contemporary camp is so involved in mass cultureindeed, generated by it - then its transcendence can never be complete.

Camp entails a kind of ironizing leveling - "the equivalence of all objects" (289); a tendency of camp that feeds into postmodern culture. Sontag both welcomed and felt unease about this development. Revisiting the issue of camp in a 1982 essay, Sontag sought to distinguish between pseudo-aristocratic camp and mainstreamed camp taste. Camp can be seen "as part of the democratizing of dandy attitudes," but it "still presupposes the older, higher standards of discrimination - in contrast to the taste incarnated by Andy Warhol, the franchiser and mass marketer of the dandyism of leveling" (Where the Stress Falls 
80). As in "Notes on Camp," the murky formulations - a democratization of elite attitudes, the franchising of the dandyism of leveling - obfuscate the way in which camp is necessarily caught up in mass culture, even if it is (or was) distanced from majoritarian modes of consumption.

The tension in Sontag's theory of camp between transcendence of and immersion in mass culture can, I suggest, be related to a tension in her career between uniqueness and seriality. One of the most remarked-upon aspects of Sontag, and one which she arguably did much to promote, is her singularity. But this singularity was also shadowed by intimations of the repetition inherent in commodity culture, or, in Sontag's phrase, the nausea of the replica. In dubbing her the "Dark Lady of American Letters," for instance, Norman Podhoretz wrote that this was a position "originally ... carved out by Mary McCarthy" (154-5). The idea is reinforced by the anecdote Sontag told, in which McCarthy, meeting her for the first time, pronounced "Oh, you're the imitation me" (Bernstein). Sontag's celebrity status was premised on her singularity but also indicated her implication in the consumer capitalism that she increasingly professed to despise. The twentieth-century celebrity system, a concomitant of commodity culture, insists on the uniqueness of the individual-it is in David Marshall's formulation a manifestation of hyper-individuality (Marshall 59) - but it is also driven by the imperatives of replacement and repetition. However, although there is a clear sense in which Sontag's career incorporates her in US celebrity culture (the photographs, the TV appearances, the articles in Vogue and 
so on), her status as a writer also places her in an ironic and complicating relation to it.

As Loren Glass argues, theories of celebrity usually focus on "corporate culture industries" such as film and TV, "in which the individual agency behind the celebrity persona is clearly vitiated, if not irrelevant" (3); such theories cannot account for the status of modernist writer-celebrities, who sustain "an ethos of individual creative production over and against the rise of [the] culture industries in which they nevertheless have ... to participate" (4). As with other modernist celebrities, "individual authorial consciousness" is central to Sontag's career, and this distinguishes her persona from that of the stars of the culture industries, in which "'celebrity' [is] the product of an impersonal system that responds to the needs of an equally vast and amorphous audience" (4).

Sontag's simultaneous embodiment and denunciation of celebrity speaks to conflicting desires to proclaim her individuality - and to claim the fame that was the due of that individuality - and to transcend it. Celebrity was the available system through which fame could be achieved, and Sontag was hardly alone among modernist writers in either ambivalently exploiting this system, or ambivalently letting herself be exploited by it. However, Sontag resisted the acknowledgement of queer sexual identity that the celebrity system, with its interest in the public figure's private life, increasingly sought to exact. In this, she sought to best a system that, with regard to the articulation of sexual identity at least, could be said to have bested her. 
In what might be seen as a last-ditch effort at this besting, when Sontag did acknowledge her queerness in the 2000 New Yorker interview, it was halfheartedly, and certainly not in relation to the term "lesbian," or indeeed the term "queer," terms which she had applied to herself many years earlier in her journals. I don't mean to accuse Sontag of bad faith in eschewing selfidentification as a lesbian, even once it became relatively "safe" to do so, as that self-identification may of course have changed in the years after she privately claimed it in her journals. Indeed, rather than instancing bad faith, Sontag's resistance to being publicly located under the label "lesbian," perhaps indicates not only the tropism towards impersonality that marked her work but also the desire to stave off the nausea of the replica - the association with commodity culture that was increasingly associated with gay and lesbian subcultural identity from the late 1960s on. One outcome of the association of queerness and postmodernity was the conception of gay and lesbian lives as "life styles" modes of consumption - and Sontag was at pains to emphasize that in her view "there is something deeply wrong if you speak of your life as your life style" as "it ... tend[s] to destroy a certain kind of spiritual possibility" (Conversations 171). Yet the associations with queerness and commodity culture were there from the start of her career and they continued to trouble it. The revulsion and nausea that Sontag in "Notes on Camp" professed in the face of the commodity and queerness were offset by, and entangled with, the way she was inescapably "drawn" to both. 
' This formulation is Clara Tuite's paraphrase of a point made by Graeme Turner in a public lecture, "Why Bother With Celebrity? Understanding the Production and Consumption of the Public Figure," delivered in Melbourne in 2003. See Tuite 60 .

\section{Works Cited}

Bernstein, Richard. "Susan Sontag, as Image and as Herself." New York Times, 26 Jan. 1989. Web. 14 Sept. 2010.

Castle, Terry. "Some Notes on 'Notes on Camp.'” Barbara Ching and WagnerLawlor Ching, eds. The Scandal of Susan Sontag. New York: Columbia UP, 2009. 21-31. Print.

Dollimore, Jonathan. Sexual Dissidence: Augustine to Wilde, Freud to Foucault.

Oxford: Oxford UP, 1991. Print.

Foucault, Michel. The History of Sexuality. Vol. 1, An Introduction. Trans. Robert Hurley. Harmondsworth: Penguin, 1990. Print.

Glass, Loren. Authors Inc.: Literary Celebrity in the Modern United States, 1880-1980.

New York: New York UP, 2004. Print.

Greif, Mark. "Still Superior." London Review of Books 12 Feb. 2009. Web. 7 Sept. 2010.

Jameson, Fredric. Postmodernism, or, the Cultural Logic of Late Capitalism. London: Verso, 1991. Print.

Marshall, P. David. Celebrity and Power: Fame in Contemporary Culture.

Minneapolis: U of Minnesota P, 1997. Print.

Miller, D.A. The Novel and the Police. Berkeley: U of California P, 1988. Print. 
---. “Sontag's Urbanity." The Lesbian and Gay Studies Reader. Ed. Henry Abelove, Michèle Aina Barale, and David M. Halperin. 212-19. Print.

Pater, Walter. The Renaissance: Studies in Art and Poetry. Ed. Adam Phillips. Oxford: Oxford UP, 1986. Print.

Podhoretz, Norman. Making It. New York: Random House, 1967. Print.

Rollyson, Carl and Lisa Paddock. Susan Sontag: The Making of an Icon. New York: Norton, 2000. Print.

Sedgwick, Eve Kosofsky. Epistemology of the Closet. Berkeley: U of California P, 1990. Print.

Seligman, Craig. Sontag and Kael: Opposites Attract Me. New York: Counterpoint, 2004. Print.

Sontag, Susan. Against Interpretation. New York: Farrar Straus Giroux, 1966. Print.

---. Conversations with Susan Sontag. Ed. Leland Poague. Jackson: UP of Mississippi, 1995. Print.

---. Reborn: Journals and Notebooks, 1947-1963. Ed. David Rieff. New York: Farrar Straus Giroux, 2008. Print.

---. Under the Sign of Saturn. New York: Farrar Straus Giroux, 1980. Print.

---. Where the Stress Falls. London: Vintage, 2003. Print.

Tuite, Clara. “Tainted Love and Romantic Literary Celebrity.” ELH 74 (2007): 59-88. 